FACTA UNIVERSITATIS

Series: Architecture and Civil Engineering Vol. 10, $\mathrm{N}^{\mathrm{o}}$ 1, 2012, pp. 17 - 32

DOI: 10.2298/FUACE1201017Z

\title{
A METHOD FOR EVALUATING THE DEGREE OF HOUSING UNIT FLEXIBILITY IN MULTI-FAMILY HOUSING ${ }^{*}$
}

\author{
$U D C 728.2: 711.58=111$
}

\author{
Milica Živković, Goran Jovanović \\ University of Niš, Faculty of Civil Engineering and Architecture, Serbia \\ dia.milica@gmail.com
}

\begin{abstract}
The flexibility of housing unit is achieved through a complex design process which includes an analysis of influencing factors of flexibility, their potentials and limitations for the purpose of improvement of residential space organization. This paper explains the proposed evaluation method of internal flexibility of housing units in multifamily housing which may be accepted as a general model. The presented method is based on the elements of multicriteria analysis, where the object of evaluation is assessed through a number of physical criteria that are directly related to the concept of flexibility. The applied methodology aims to determine the best combination of criteria parameters, on the base of which further guidelines in flexible housing design are given.
\end{abstract}

Key words: housing unit, flexibility, evaluation, multicriteria analysis.

\section{INTRODUCTION}

Flexibility, as an innovative approach to architectural design, sets the variability as a relevant parameter of space design. This requirement is especially related to the field of housing, where the complexity of the relationship between users and their immediate environment requires special attention. The evolution of social behavior leads to new conceptual solutions of modern living, new principles of housing unit design and its immediate environment. Residential environment should be designed to respond to the modern living demands, with the idea of flexibility as a key feature of design approach. In the field of housing, such an approach would imply the identification of those structural and functional characteristics of living space that affect the degree of flexibility.

In multi-family residential buildings, housing unit is a primary structure that would, through its flexible organization contributed to the quality of life in such an environment.

\section{Received December 06, 2011}

* Acknowledgement: The paper is a part of the research done within the project "Optimisation of architectural and urban planning and design in function of sustainable development in Serbia", (TR36042), funded by the Ministry of Education and Science, Republic of Serbia. 
The apartment is a basic physical framework of the family as a primary social group that should, through its development phases, respond to the changing needs of the demographic, economic, environmental and technological aspects of society. The aim of this research is improvement of flexible design principles within defined spatial frame of housing unit (internal flexibility), which is based on the concept of interdependence of the typical design factors. The flat decomposition to the unchanging parts and those that are organizationally and substantively changeable as well as the definition of design aspects that influence flexibility, is the first step in finding the optimal solution to the problem of variability of needs. The most important determining characteristics of the plan are, therefore, offered as basic aspects of flexibility. Thereby, it is necessary to prove that no single factor can lead to an optimal solution, but is the result of combination of numerous, interdependent factors whose relationship determines the degree of achieved flexibility. The paper uses a subjective evaluation method based on predefined criteria of flexibility. The analysis of housing unit examples that are characterized by some degree of internal flexibility, sets out the observations on actual qualitative results and provides further guidance in living space design. The flexibility of analyzed solutions range from extremely limited to absolute on the base of which the apartment use-value is determined. The ultimate research goal is to create a rational basis that could be accepted as a general model and implemented in the design of flexible living space.

\section{The Concept of Constant And Changeable in the FleXible Design}

The term of housing, in the context of architectural design, is usually described by the physical dimension of the apartment. The properties of physical dimension include all residential properties and norms such as size of the apartment, its structure, lighting, open spaces, infrastructure etc., that, in certain way, define the spatial configuration of the assembly. Flexibility, as an aspect of the flat use-value, requires the development of new design concepts that meet the unpredictable changes in the housing program. These changes indicate differentiation of plan characteristics in terms of their spatial determination, in other words, identification of fixed and variable factors of architectural space. Defining the relationship between "static" and "dynamic" categories in physical framework of the apartment is the first step in developing an evaluation model of plan flexibility. The unchangeable, fixed determinations include all structural, layout, and installation solutions that deliver architectural and functional determination to the space and cannot be changed or need special construction works. The unchangeable aspects of residential space consist of features such as access (communications), supplying elements (installation), envelope, construction (columns, beams, floor construction, bearing walls), location (context) etc. The changeable aspects are presented as spatial characteristics in free interpretation that are the most direct indicators of the degree of achieved flexibility. The designing process firstly defines the position of unchangeable segments on which the functionally and spatially variable part of the flat is built. The design of changeable part is more complex process because it has to meet a number of individual conditions that, in the certain stages of exploitation, should ensure uninterrupted use of the apartment.

The basic idea is, therefore, to define in the earliest stages of design those groups of spatial criteria which are objects of physical changes and those that are, in physical sense, 
permanently defined. Analysis of the aspects that permanently and irreversibly define usevalue and possible spatial and functional configuration of residential unit, is the first step in evaluating the degree of achieved flexibility. It is, therefore, necessary to consider specific cases of spatial flat arrangement in order to make an optimal spatial and functional synthesis in the field of flexible design, taking into account the individual aspects of flexibility.

\section{SPATIAL ASPECTS AND CRITERIA FOR FLEXIBILITY EVALUATION}

The evaluation of flexibility of usable flat space in multi-family housing is a complex and demanding procedure, which cannot be implemented without using the results of certain long-term research in the field of housing. However, previous studies of flexible housing are quite meager so the attitudes exhibited in this work are mainly based on experience of individual authors and data taken from some prior literature. Among the leading local authors and prominent designers who were engaged in research of housing flexibility are M. Čanak, D. Marušić and M. Lojanica. Most of these studies, which have undoubted theoretical importance, remained in the area of the proposal, because they didn't include detailed elaboration of dimensional, organizational and other criterion parameters of flexibility. These parameters are based on John Habraken's theory stating that the flexibility of living space arises from the quality organization of basic, unchangeable aspects of the building or so-called "structure" [3]. In the design process, it is necessary to thoroughly analyze all usage potentials of living space with recognizing the impact of immutable physical aspects of the design process, on the base of which the key characteristics of flexible plan are identified.

In order to define the possible evaluation model of achieved level of flexibility in terms of housing unit, it is therefore necessary:

- to identify those physical design aspects that recognize the differences in the flat use-value and relate to the spatial organization and fixed determinations of the flat,

- to evaluate the examples of flexible housing units by using selected evaluation criteria in order to identify the achieved degree of flexibility, in compliance with the established differences in quality and use-value of the apartment.

Housing needs and their level of satisfaction through the spatial organization of the apartment are criteria that determine its use-value. The supposed measurable aspects that largely influence the flexibility and thus the utility value of residential space are:

- orientation of housing unit (one-sided, two-sided or three-sided orientation),

- geometry of plan (dispersed or compact form of housing units),

- structure and size of the flat (relationship between structure and size of the flat and family structure),

- number and disposition of the entrance (central or peripheral),

- position of technical services (grouped or individually placed, with the central or peripheral position)

- building structure (massive or skeleton structure) [9]. 
In the process of evaluating the quality of generated solutions, it is also necessary to identify the evaluation criteria or features of flexible flat organization. This paper discusses the following criteria that determine the spatial quality of the internal flexibility of the plan:

- achieved degree of freedom of interior space, or to what extent the organization of interior space is conditioned by the position of fixed elements of the plan,

- potential for multifunctional use of space, or the ability to change the function of rooms without changing their spatial dimensions,

- changes in number and size of the rooms which implies that the space division is changeable and possible with using of flexible partitions.

\section{INFLUENTIAL FACTORS OF FLEXIBLE DESIGN OF HOUSING UNIT}

Further, the paper analyses and evaluates the qualitative characteristics of alternative housing solutions for individual spatial aspects of flexible design. All presented examples are characterized by some degree of flexibility, from absolute to highly restricted, where the qualitative ranking of achieved individual results provide general guidance in further development of this approach.

\subsection{Orientation of housing unit}

Orientation of housing unit, in terms of position and number of facade planes greatly influences the spatial organization of apartment and achieved level of flexibility. This paper discusses three types of housing unit orientations that are mostly found in practice:

- one-sided orientation (housing unit relies on one side of the facade),

- two-sided orientation (two adjacent or two opposite exterior sides),

- three-sided orientation (housing unit has access to three exterior sides).

Examples given for all three types of housing units are about the same size and dimensions in order to get more relevant results in comparative analysis. The degree of achieved flexibility, in the context of housing unit orientation, cannot be evaluated separately from the features such as geometry and size of the unit. Zoning of residential area was implemented in order to facilitate the consideration of possible physical intervention within a plan. Two main areas of flat were identified: fixed unchanging zone and zone in free interpretation [5].

Housing units with one-sided orientation condition clear differentiation of the zone with auxiliary rooms that do not necessarily require natural light and ventilation, from the area with the main residential rooms, that require natural insulation and ventilation. In such cases, especially of smaller size flats, one often resorts to the solutions in which the use-value of certain flat facilities are consciously sacrificed for the sake of overall quality of the plan. An example of a one-sided flat orientation is shown in Figure 1, made as a part of conceptual design for the apartment block "MOZAIK" in Niš. The entrance area and installation blocks of kitchen and bathroom are positioned in the inner zone of the apartment, along communication area of the object and represent strictly defined, fixed zone of the flat (zone A). Living areas for longer stay during the day are planned along the building facade zone and represent residential zone in free interpretation (zone B). As a result of one-sided orientation of the apartment, due to the lack of space for accommodation of all residential premises, the dining room is forcedly placed in an extended communication with low insolation and natural ven- 
tilation. Flexibility of spatial solution is limited by the fact that the residential rooms can be positioned only along one side of the building facade and variations of the plan are reduced to a minimum. In this case flexibility of spatial organization mainly involves changing the use of certain rooms within the flat, and therefore, it is desirable to design the rooms as multi-functional and multipurpose. Such spatial configurations are often characterized by unclear zoning of complementary functions within the flat as a result of strictly defined and conditioned position of the zone in free interpretation. Negativity of orientation in such cases can be reduced by design of larger units with a wider facade front.
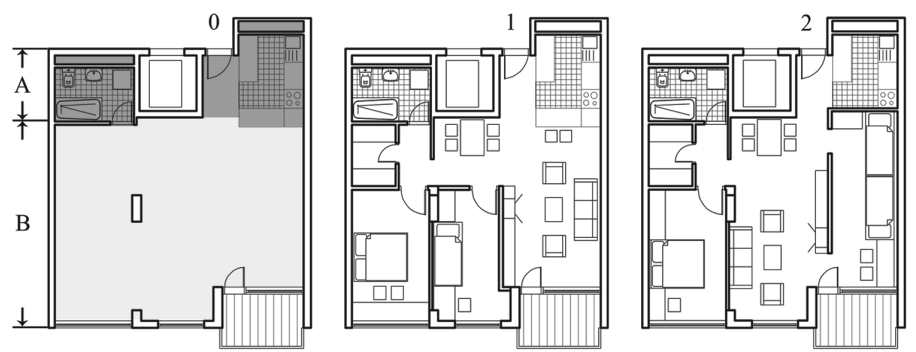

Fig. 1. One-side oriented apartment with defined zones A and B (0) and alternative solutions of the unit $(1,2),[4]$

Solutions with two-sided flat orientation have a greater degree of freedom, while the flexibility of spatial solutions largely depends on plan geometry and relationship between the facade walls. Square forms of the plan are, in this case, better solution than elongated forms as they provide more options in terms of space division. The solution with twosided orientation with facade walls on the opposite sides of the housing unit allows clearer facilities zoning compared to the solutions with the facade walls on adjacent sides. In these solutions, variations in the spatial plan, in terms of changes in size and position of a useful spaces, are greater because the rooms can be located along two opposite flat facades. Figure 2 shows an example of two-sided orientation and facade walls on the opposite sides of the unit. Residential zone, which extends along two facades (zone B), is possible to divide in different ways, without sacrificing its usage quality. This spatial plan solution provides opportunity of clear zoning of complementary functions within the flat.
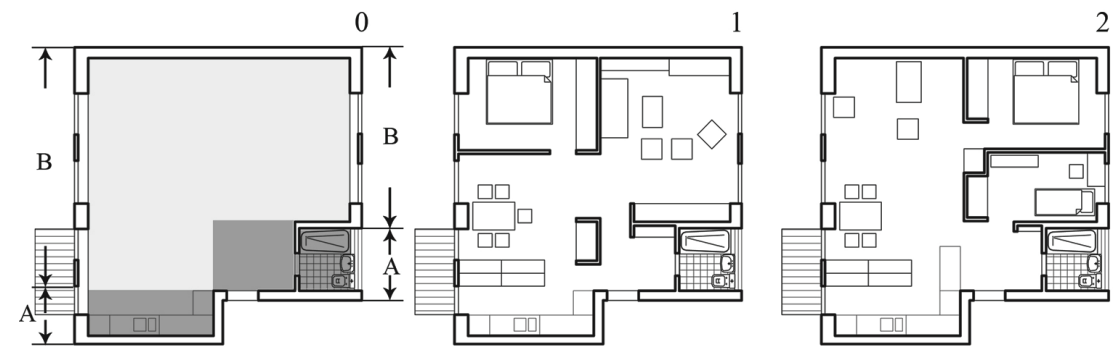

Fig. 2. Two-side oriented apartment with defined zones A and B (0) and alternative solutions of the unit $(1,2),[5]$ 
Solutions with three-sided flat orientation provides the greatest opportunities in relation to the previously analyzed cases. The living area can be oriented along the three available exterior walls, with more spacious and flexible zone in free interpretation. The solutions are characterized by a greater degree of freedom of interior space and numerous variations in the number, location and size of residential rooms. In this case, quality and flexible solutions within the housing units with greater depth can also be obtained. This kind of example is an apartment in residential block Wohnzeile in Stuttgart (Figure 3). Fixed flat area is located in the interior zone of the building while the zone in free interpretation extends in elongated form to three facade sides. In this case, position of auxiliary spaces affects the fixed position of the zone with day and night regimes. With different solution of installation blocks, such limitations can be overcome.
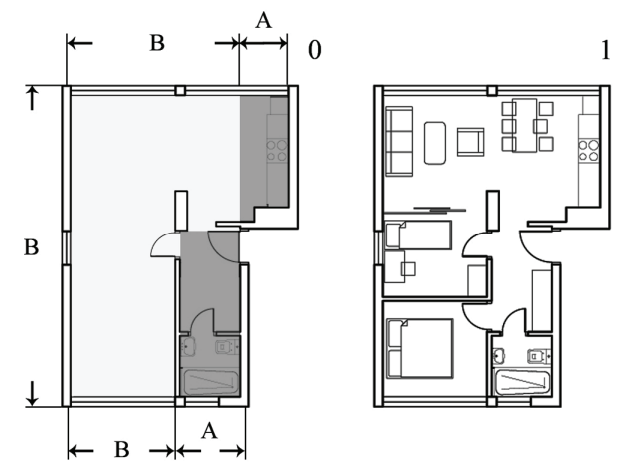

1

2

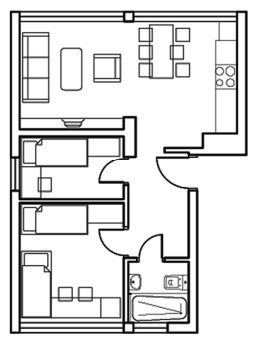

Fig. 3. Three-side oriented apartment with defined zones A and B (0) and alternative solutions of the unit $(1,2),[11]$

From the aforementioned it can be concluded that with increasing number of available facade planes of housing unit, variability and flexibility of space also increase. Therefore, the preferred solutions are those with smaller number of housing units per floor.

\subsection{Geometry of housing unit plan}

Form of the flat plan affects the degree of achieved flexibility by the fact that the possibilities for space re-allocation, multifunctionality and changes in number and size of the rooms are greater with more compact and reduced geometry.

Figure 4 presents an example of residential unit in the block Liman II-south in Novi Sad, with a quite jagged plan, with not many options left for flexible use. Due to the clear and almost strict allocation of facilities within the unit, as a result of defined surface area of individual rooms and enhanced jagged form of the plan, the potentials of flexible application have been reduced to a minimum. In the case of the given apartment, changes would be only possible with relocation of the dining table from the room intended for dining to the kitchen area, with the aim of getting space for one more bed. The quality of obtained solution is questionable because increase of flat structure and number of the users whom this structure is intended to, doesn't involve improvement of flat use-value. The plan solution doesn't match dimensional requirements of defined design standards. 

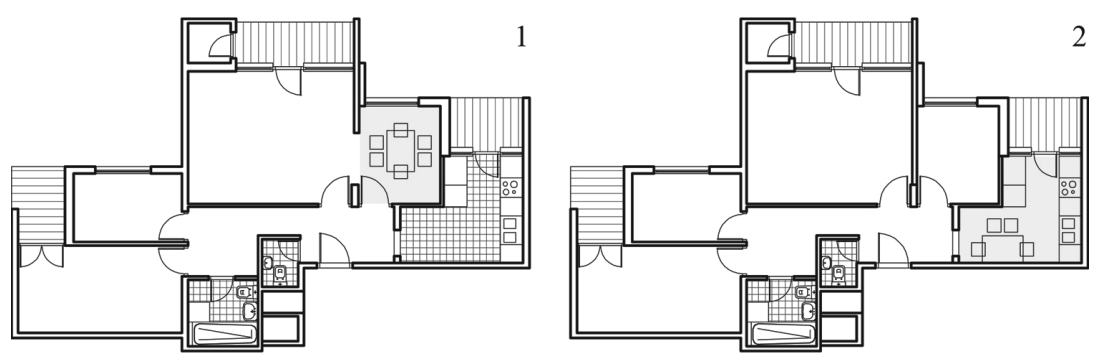

Fig. 4. Example of residential unit with jagged form of the plan, [11]

Figure 5 presents an example of unit within the residential block in Ingolstadt, whose plan is designed in a compact, rectangular form measuring $9 \times 11 \mathrm{~m}$. The central entrance, toilet and kitchen are stripe grouped into a fixed flat zone while the rest of the space, in the form of square, is left neutral and free for various interventions. Concept of an "open plan" achieves the greater flexibility of interior space, because the use of undefined polyvalent residential area can support unpredictable functions that appear over the time. Windows position, which is placed in the same rhythmic sequence, along the two opposite exterior sides, indicates a possible redistribution of housing area in defined modular net of $120 \mathrm{~cm}$. This solution of form of the plan enables clear zoning of complementary functions within a residential zone.
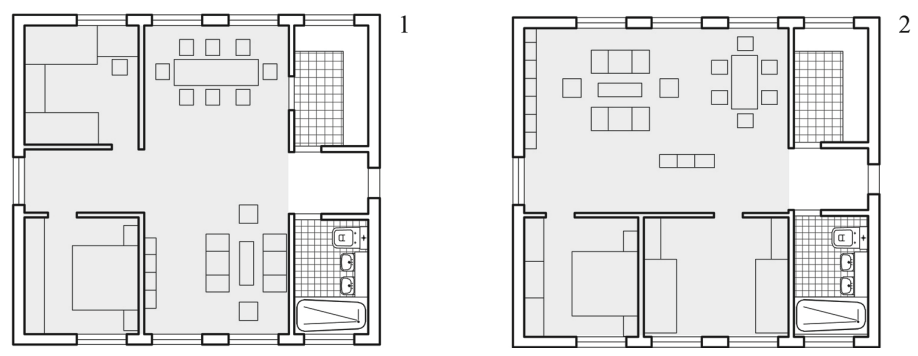

Fig. 5. Example of residential unit with compact form of the plan, [11]

Space with the characteristics of flexibility would, therefore, be designed in more compact and proper form, without major brakes and changes in layout, because, in this case, the space division is simpler and diverse. Based on the analysis of functional schemes it also can be concluded that fixed, unchanging parts of the apartment should be grouped and zoned so the rest area remains free for spatial interventions.

\subsection{Structure and size of the flat}

As the family represents "a product of evolution, elastic unit that adapts to the influences from outside and inside, it experiences significant shifts in each intermediate stage within one generation" [14]. Therefore, the changeable family structure necessarily requires the variable flat structure. Static, non-developmental flat structures cannot meet the 
wide range of needs of family and its individual members. Very often in practice, family members have to adapt to physical conditions rather than flexible space follows dynamics of the family.

Housing unit flexibility, in terms of changes of its structure, is one of the possibilities for expanding its use-value. The flat structure much more influences its use-value than the flat size. In practice, it is common that the flat structure results from defined size, but more correct procedure is one in which the structure defines its size. The degree of room variety, on the other hand, depends on defined size of the apartment. It is logical that the ability of varieties are less in case of smaller size, or less number of rooms and vice versa. Any "functional" or structural features of the apartment cannot compensate its insufficient size. According to this, discussion of functional and structural characteristics of certain flat types is not relevant under a certain size of residential space. "Under-dimensioned flat is a social and economic harm, oversized one is economic unreality" [14], so the only answer to the problem of flexibility is the flat which is developing together with the family. Therefore, the flat size should be adapted to increasing number of tenants while at the same time it "stays within the limits that in social terms, and in terms of comfort can be accepted without further notice" [2].

Changes that occur in the family are primarily caused by developmental stages such as birth, growth and departure of children from the family home. For the family at an early stage of development (or a young couple with one small child) required flat structure is two-room flat, in other words, one bedroom flat. However, if the apartment is not elastic enough, in later stages of development, the requirement of having own space for sleeping for every member of the family, won't be fulfilled. From this perspective, the flexibility of flat structure is justified for a three-member family which can be defined as "biological minimum". As this family structure requires two and half-room flat, it is necessary to define its approximate size that would provide further flexibility of the structure. According to the Conditions and technical standards for design of residential buildings and flats [15] this size is defined as the maximum surface area of $70 \mathrm{~m} 2$. This quadrature allows the flat organization with parents' and single-child bedroom but also provides sufficient degree of flexibility of flat structure in terms of variability in number and disposition of the rooms, in case of possible family extensions. Therefore, a structure designed for threemember family (two and a half room flat), with approximate quadrature of $70 \mathrm{~m} 2$, is adopted as the lower limit in flexible concept.

In practice, the solutions can be found where one-, two- and three-room flats are transformed in one and a half-, two and a half- and three and a half-room flats, at the cost of quality reductions of organizational and dimensional parameters. Figure 6 shows three variants of flexible flat in Bežanijska kosa, designed for three different types of families: two-member, three-member and four member family. The basic two-room flat has size of $61.5 \mathrm{~m} 2$, which is planned for structure enlarging to obtain two and a half- and, in a later stage, three-room apartment. First variant is designed for a young married couple without children or with one small child (up to 6 years) that can sleep in their room. Useful flat facilities include parents' room, dining room and living room that function as two independent gathering centers. In second variant, transformation of the dining room in a single child's bedroom and relocation of the dining table in the kitchen area, provides transformation of two-room flat to two and a half-room flat. The third option is made by moving the partition wall between the dining and living room (first variant) for making children's 
room in the area of former living room. The expanded dining area becomes a living room with space for dining. At this stage the defects in structure and organization of the apartment can already be observed. The lack of one more sanitary block prescribed by standards, bad connection between the children's rooms and existing toilet, and insufficient surface area of the living room are directly related to inadequate surface area of the initial plan. By increasing the size to $70 \mathrm{~m} 2$, which is defined as the minimum standard for a family group in a stable stage of development (families with two children aged 12 years), these shortcomings could be overcome.

1

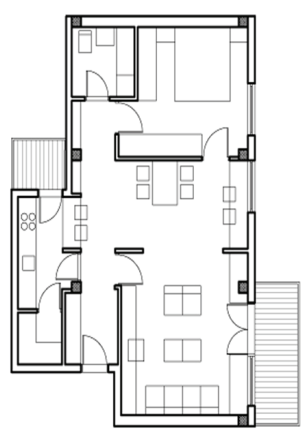

2

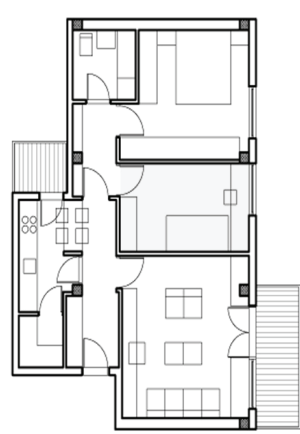

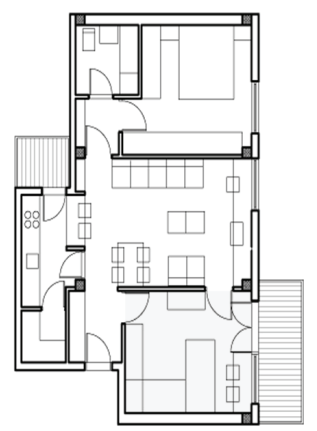

Fig. 6. The flexible flat structure intended to two, three and four-members family, [6]

Flexibility of spatial organization, therefore, should provide a flexible flat structure, which would accommodate to conditions of dynamic changes of household within the framework of adopted housing standards. Implementation of standards is provided at certain time stages that are correlated with the developmental stages of families, ranging from maximum to minimum standard and vice versa (from increasing to reducing structure of the family group).

\subsection{Number and disposition of the entrance}

The entrance position, relative to the outline of housing unit, significantly influences the spatial organization of the flat and the current level of flexibility. This paper analyzes two disposition of the entrance:

- central and

- peripheral.

The central entrance position is usually the best option for flexibility. This position allows the shortest possible link with all parts of the apartment. The peripheral position of the entrance is unfavorable solution, especially in larger apartments. It causes its elongated position and increases surface area for communication. Also this entrance solution conditions defined position of the day and night zone. Variations of spatial solutions are largely possible only within individual zones, taking into account the rule of the short and direct entrance connection to the living room zone. Figure 7 presents an example of the apartment block Liman II in Novi Sad, designed with the idea of external flexibility. In- 
ternal flexibility of housing units has been reduced to a minimum with peripheral position of the entrance zone which is connected with living room, kitchen and dining room. The only spatial interventions are possible within the night zone by moving or omission of partition walls.

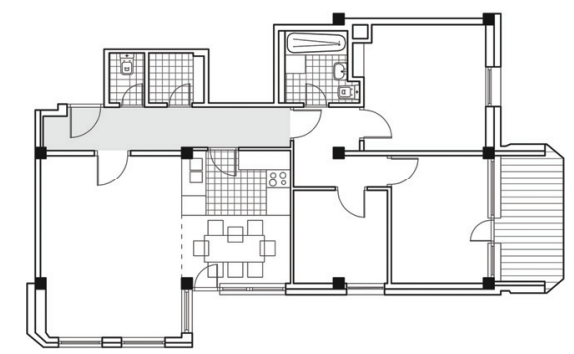

Fig. 7. Example of residential unit with peripheral entrance position, [7]

Figure 8 shows an example of residential unit developed during the conceptual design of apartment building "MOZAIK" in Niš, with a centrally positioned entrance. Shown alternative solutions indicate the possibility of rotating the position of day and night areas, without compromising the quality of functional organization and relationship between the entrance area and individual functional areas of the apartment. Entrance zone, in this case, has a clear and direct connection with all relevant parts of the apartment.
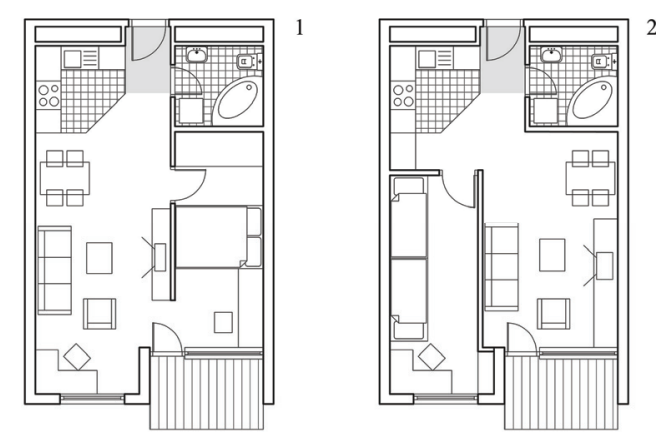

Fig. 8. Example of residential with central entrance position, [4]

With increasing number of the entrances, particularly in the larger size units, it is possible to achieve a higher degree of functional flexibility, which primarily involves the disposition replacement of the day and night zone in relation to the entrance zone. Figure 9 presents an example of residential unit in the block "MOZAIK", which is formed by merging of two dwelling units into one. It is evident that the area of kitchen and living room can be formed along the entrance zone from the left or right side of the unit, so the number of alternative solutions is greater. In this way, negativity of peripheral entrance solution, which requires strictly defined organizational scheme of relationship between individual zones within the housing units, is overcome. 

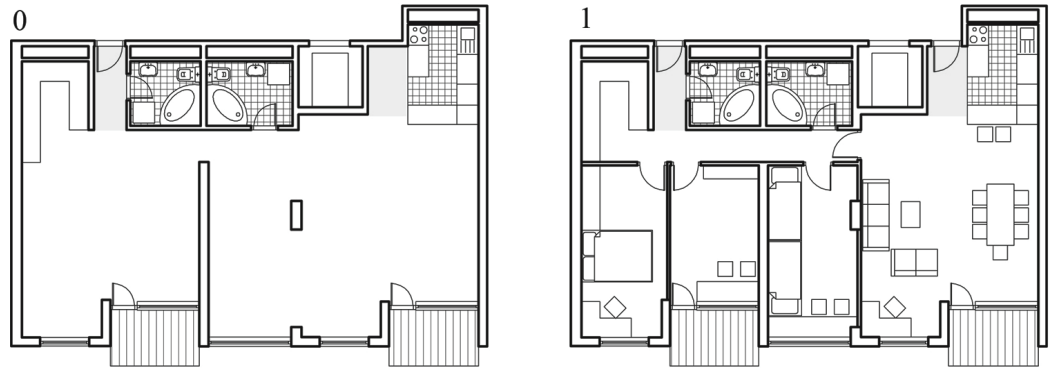

Fig. 9. Example of residential unit with two entrances, [4]

\subsection{Position of technical services}

The position of technical installations is one of the basic unchangeable aspects of residential space. The key role of this part of design process for housing unit flexibility is conceivable through the fact that these parts are the most inflexible elements of the unit. Therefore, the issue of structuring the technical core is important to consider and resolve in the initial design phase, in order to give more flexible solution in exploitation.

The technical core, which consists of installation blocks and walls, can include a variety of functions, such as bathroom, toilet, wardrobes, kitchen and vertical communications. The position and number of core elements and the associated functional processes that are taking place around them, affecting the possible ways of unit organization. Position of technical services within the housing unit can be:

- free-standing, in the central area of the apartment,

- central, along one or more walls of the apartment,

- structured along the wall between two flats [8].

Prefabricated elements (installation blocks and partition walls) set into a single formation of technical core allow a higher degree of flexibility of functional organization along its edges. Around its edges, depending on required purpose of certain parts of the unit, the connections to water supply, sewerage and ventilation building systems can be organized in different ways. In this kind of unity spaces such as kitchen, bathroom, toilet, storage, internal hall, internal vertical communication (stairs and elevator if the apartment is organized in several floors) and wardrobes can be partially or completely grouped.

Design of a free-standing technical core in the central zone of the apartment achieves various solutions of spatial flat organization around it. This solution of residential unit provides access to all sides of technical core and encourages the formation of the socalled "circular connection" in the apartment. In a significant number of examples, the technical core organized in this way is set orthogonally relative to the flat grid, while the diagonal positioning is less represented. This solution of the technical core is mostly found in larger size apartments. Figure 10 presents an apartment in multi-family dwelling Neuwil in Switzerland, with a centrally positioned, free-standing technical block. Technical block in its composition includes toilet, kitchen and vertical communication, and only their function and position are predefined. Purpose and reordering of the rest of the resi- 
dential area are not predetermined, but left open for individual interpretation. As the quality, size and orientation of the rooms on the east and west side of the flat are almost identical, it is possible to position the day and night zone in different ways and reallocated the space within them. This solution enables the formation of direct communication links between rooms or the so-called "circular connection" in the flat, which increases the utility value of the apartment.

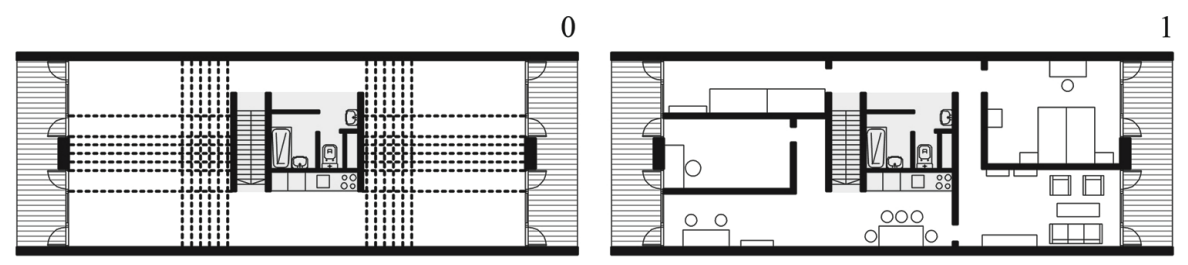

Fig. 10. Example of free-standing technical core in central zone of apartment, [11]

Centrally positioned cores along one or more walls of the unit can separate day and night zone by corridors. Figure 11 shows the housing unit in block Griesgofgasse in Vienna, with a centrally positioned technical cores on two opposite walls of the apartment. Entrance and installations of toilet, bathroom and kitchen constitute a fixed flat zone from which one can access all other rooms. Each room is characterized by functional neutrality and multiplex connections with the central area of the apartment. In this, as in the previous case, it is possible to rotate the functions with day and night mode.
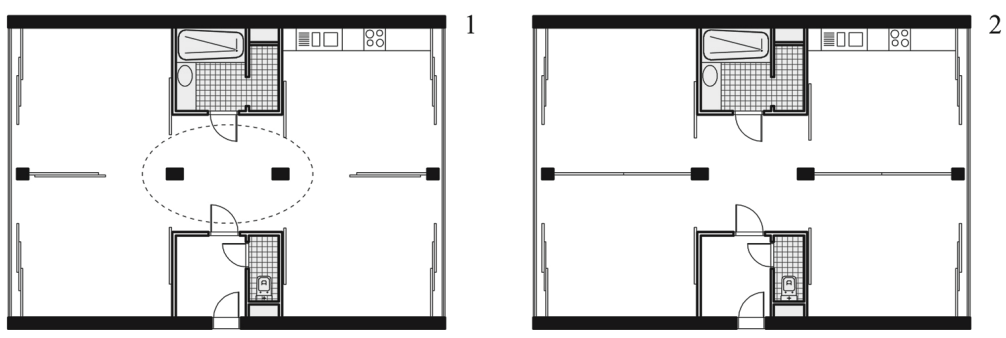

Fig. 11. Centrally positioned technical core along two opposite walls of the flat, [11]

When the technical core is set along a wall between two apartments it is very often necessary to form one or more additional verticals, especially in the case of larger apartments. In this case, the different typologies of technical cores are observed. Residential unit in the settlement "Krnjevo" in Rijeka was designed with the idea of flexible use of space, in accordance with the changing structure of family group. However, defined fix positions of installation blocks along the walls of adjacent apartment and common area of the building, quite limit the opportunities for quality solution of space reorganization. This comes from the fact that the position of some residential areas is conditioned by position of installation core, so the offered alternative solutions are characterized by unclear differentiation of functional areas in the flat (Fig. 12). 

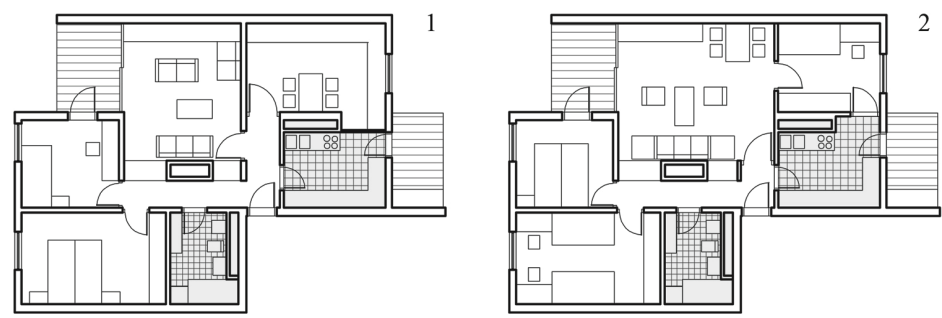

Fig. 12. Housing unit with technical blocks positioned along the wall between two apartments and common building area, [13]

Based on the presented examples, it can be concluded that the centrally positioned core can provide the highest degree of unit flexibility. It provides rotation and replacement of day and night functions structured around it. Central core set along one or more walls contributes to the possibility of combining of spatial organization in relation to biological rhythms. The technical core positioned between two flat walls disables circular connection and rotation of the zones within the initial units.

\subsection{Building structure}

The structural system, as rigid and unchanging part of the housing unit, dictates the degree of flexibility of spatial unit set. The current trend in design is characterized by "adjustment of contemporary structural system to the needs of architectural requirements in relation to the function, organization, etc." [10]. Modern building structure should be characterized by "material durability, conceptual flexibility and overlap of physical and functional life of construction and object" [10]. This paper comparatively analyzes two systems of construction, which usually occur in practice:

- massive structural system and

- skeletal structural system.

Comparing the massive and skeletal structural system, it can be assumed that the surface system with its structural elements limits the flexibility and hinders the formation of rooms at least in one direction, unlike the skeleton system that gives greater possibility of space division. At this point, it is necessary to emphasize that flexibility of an apartment with a massive structural system is threatened only if the structural elements are located inside a plan. Application of larger spans makes possible to overcome these shortcomings.

Degree of flexibility of massive structural systems depends on the direction of supporting panels inside the apartment. In the case of buildings constructed with transverse and longitudinal walls, the level of space flexibility is minimized because the fixed structural elements limit the space on all sides. For the buildings constructed with longitudinal bearing walls, level of space flexibility is larger. Sub-system of partitions is formed in longitudinal direction and can be moved within the plan. When building is made of transverse supporting elements, flexibility is possible in the longitudinal direction. Flexibility is generally achieved within the limits defined by distance of transverse load-bearing walls. The main obstacle in space organization, in this case, is a deficiency of optimal environmental conditions such as adequate lighting, ventilation, etc. 
The skeletal structural system should allow the greatest level of flexibility because the openness of the plan is realized in two orthogonal directions. Limiting factors in this case might be the dimensions and positions of structural elements. Columns with their dimensions can disturb the spatial organization of the apartment. The partition walls cannot be placed arbitrarily, but they are connected to the load-bearing structural elements. On the other hand, the omission of partitions in the plan is simple, which is difficult to obtain in the case of massive structural system.

In domestic practice, the massive structural system proved to be less flexible in relation to the skeletal system. A study of utilization of flexible potentials is made on this topic for certain number of residential buildings in Novi Sad, designed in the period 19771996. The building block in Liman II-south, designed in 1979, in prefabricated skeleton structure IMS (Fig. 13), has the percentage of used potential of flexibility of $40.21 \%$. The building Ic, designed in 1983, in the classical system of load-bearing reinforced concrete walls (Fig. 14), has the percentage of used potential flexibility of $24.69 \%$.
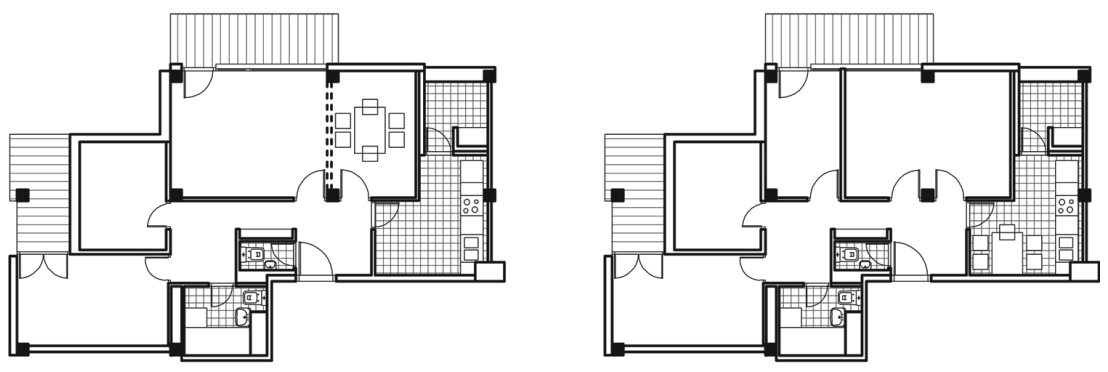

Fig. 13. Apartment built in skeletal structural system, [7]
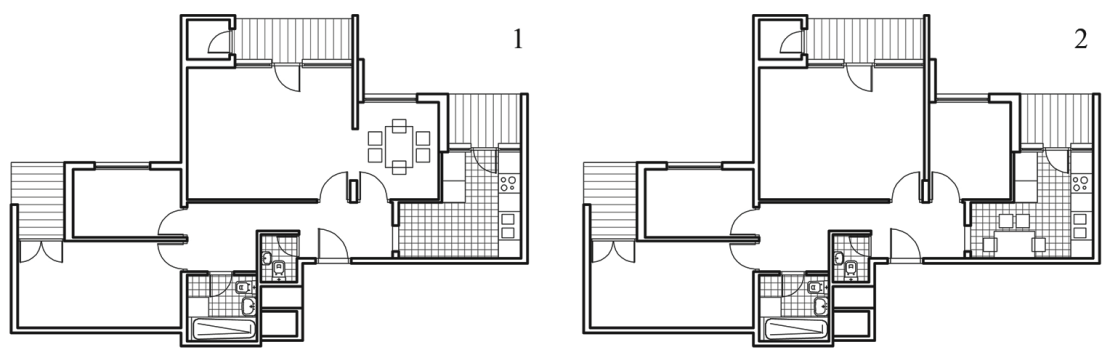

Fig. 14. Apartment built in massive structural system, [7]

Taking into account all the characteristics, both structural systems have advantages and disadvantages. In conclusion, remains on designer to determine the structural system to be applied in the design, depending on design task, because neither structural type has only advantages or disadvantages. 


\section{CONCLUSION}

This paper presents a method of subjective evaluation of the degree of achieved internal flexibility of housing unit in multi-family housing. The evaluation method is based on the concept of interdependence of the factors that, in physical sense, determine the course of flexible design. In order to obtain the best possible solution, it is necessary to define the groups of spatial characteristics that are permanently defined and those that are object of physical changes. Analysis of the aspects, that permanently and irreversibly define the quality of spatial and functional organization, is the first step in evaluating the degree of housing unit flexibility. Orientation, plan geometry, structure and size of the apartment, disposition and number of entrances, the position of technical installations and applied structural system are presented as the factors that mostly influence the achieved level of flexibility. In order to make a contribution in this research field, it is necessary to consider the typical cases of spatial flat arrangement for individual factors of flexibility. In the process of evaluation there are defined the spatial criteria such as: the degree of freedom of internal space, the potentials for its multifunctional use and the possibility of changing the spatial solutions in terms of number and size of the rooms. All examples that are objects of evaluation are characterized by some degree of flexibility, from absolute to highly limited, on which base is determined the optimal combination of spatial aspects.

Upon review of optimal characteristics of spatial unit solution, the principles of flexible design of housing unit are adopted. In terms of orientation, the optimal design solution is housing unit that has access to as many facades as possible. If location conditions and conditions defined at the level of building stock limit the possibility of exit to outer space, it is desirable to design a smaller number of units per building floor. Flexible flat should also be designed with more compact and regular form of the plan, without major fractures and changes in the outline, because, in this case, degree of freedom of internal space is greater and the possibilities of its redistribution are more diverse. Elastic flat structure is one of the important characteristic of flexible design, which should follow the dynamic changes in the household. Apartment size is defined in terms of spatial norms that are changing in certain time stages, in line with the developmental stages of families. It is, therefore, necessary to define what the allowable minimum standard that provides acceptance of family group at its most loaded development stage is. Disposition of entrance also affects the flexibility of housing units, while the central position is the best solution. It allows its clear connection with all functional areas of the apartment which, therefore, may change their position in the plan. In case that the apartment size allows design of multiple entrances, the flexibility of this structure would be improved. Grouping of technical installations is also an important initial item in flexible design. A centrally positioned installation core provides the greatest degree of flexibility because it is possible to organize the space around it in different ways. The current technological level still conditions close connection between space and structure from which a strong structure impact on the plan flexibility is derived. Selection of structural system depends on design task and choice of designer because the both analyzed systems, massive and skeletal, have their advantages and disadvantages.

On the basis of all presented, it can be concluded that the identification of certain physical aspects of the apartment, their analysis and evaluation prevent the problems of flexible organization and make a positive shift in the field of housing. 


\section{REFERENCES}

1. Baylon, M., "Tema 1: Organizacija stana", materijal sa poslediplomskih studija, kurs Stanovanje, Arhitektonski fakultet, Beograd, 1979.

2. Ferenčak, M., "Razvojne sinteze i nerazvojni elementi grada, Jugoslovenski institut za urbanizam i stanovanje, Beograd, 1966.

3. Habraken, N., J., "Ka principu struktura u stanovanju", Savetovanje: Primena SAR-metoda u projektovanju stanova I u razvoju industrijalizacije stambene izgradnje", Portorož, 1975.

4. Jovanović, G., "Flexible organization of floor composition and flexible organization of dwelling space as a response to contemporary market demands", Facta Universitatis, Series: Architecture and Civil Engineering, Vol. 5, No 1, 2007.

5. Knežević, G., "Višestambene zgrade", Tehnička knjiga, Zagreb, 1984.

6. Kovačević, S., "Projekat stambene zgrade u IMS sistemu", Bilten IMS, br. 5-6.

7. Krstić, D., Realna interna fleksibilnost strukture stanova u stambenim zgradama za kolektivno stanovanje", Stanovanje ka III milenijumu, 2001.

8. Kubet, V., Carić, O., Hiel, K., "Fleksibilnost stambene jedinice u odnosu na grupisanje instalacija", Zbornik radova Građevinsko- arhitektonskog fakulteta u Nišu, broj 25, 2010.

9. Moharram, L., A., "A method for evaluating the flexibility of floor plans in multy-story housing", A dissertation in architecture, Unicersity of Pennsylvania, 1980.

10. Samardžić, M., "Fleksibilne konstrukcije u stanovanju", Arhitektonski fakultet, Beograd, 1991.

11. Schneider, T., Till, J., "Flexible housing", Architectural press, London, 2007.

12. Soboljevski-Miljić, V., A., "Fleksibilnost stambenog prostora uslovljena odabranim prefabrikovanim sistemom", Zbornik radova sa naučnog skupa: Unapređenje stanovanja '98, Beograd, decembar 1998.

13. Stoiljković, B., "Fleksibilnost stanova namenjenih tržištu", Zbornik radova Građevinsko-arhitektonskog fakulteta u Nišu, broj 20, 2004.

14. Tomova, S., D., Uticaj dinamike porodičnog života na strukturu i optimalnu veličinu stana i njena zavisnost sa dinamikom strukture stanovništva", Savetovanje o društvenom organizovanju usmerene stambene izgradnje, Skoplje, 1974.

15. Uslovi i tehnički normativi za projektovanje stambenih zgrada i stanova, Građevinska knjiga, Beograd, 1984.

\section{METOD VREDNOVANJA STEPENA FLEKSIBILNOSTI STAMBENE JEDINICE KOD VIŠEPORODIČNOG STANOVANJA Milica Živković, Goran Jovanović}

Fleksibilnost stambene jedinice ostvaruje se kroz kompleksan proces projektovanja koji uključuje analizu uticajnih faktora fleksibilnosti, njihovih potencijala $i$ ograničenja, u cilju unapređenja organizacije stambenog prostora. U ovom se radu obrazlaže predloženi metod vrednovanja interne fleksibilnosti stambenih jedinica kod višeporodičnog stanovanja koji se može prihvatiti kao uopšten. Prikazani metod bazira se na elementima višekriterijumske analize, gde se predmet vrednovanja ocenjuje preko određenog broja prostornih kriterijuma koji su u direktnoj vezi sa pojmom fleksibilnosti. Primenjena metodologija ima za cilj određivanje najpovoljnije kombinacije kriterijumskih parametara, na osnovu čega se daju dalje smernice u projektovanju fleksibilnog stanovanja.

Ključne reči: stambena jedinica, fleksibilnost, vrednovanje, višekriterijumska analiza. 